\author{
재배지역별 사일리지용 옥수수 일반생육 및 수량 반응 \\ 손범영 ${ }^{1} \cdot$ 김정태 $^{1} \cdot$ 이진석 $^{1} \cdot$ 백성범 $^{1} \cdot$ 김욱한 $^{1} \cdot$ 김종덕 $^{2} \cdot$ 고기환 $^{3}$
}

\title{
Response of Growth Characteristics and Yield of Silage Corns at Different Regions \\ Beom-Young Son ${ }^{1}$, Jung-Tae Kim¹, Jin-Seok Lee ${ }^{1}$, Seong-Bum Baek ${ }^{1}$, Wook-Han Kim', Jong Duk $\mathrm{Kim}^{2}$ and $\mathrm{Ki} \mathrm{Hwan} \mathrm{Ko}^{3}$
}

\begin{abstract}
This study was carried out to compare growth characteristics and yield of silage corn hybrids at four different regions (Hwaseong, Dangjin, Gochang and Pyeongchang). Two domestic corn hybrids, 'Kwangpyeongok' and 'Gangdaok', and two imported corn hybrids, 'P3394' and '32P75' were used in this study. Plant height and ear height ratio were not significantly different among corn hybrids. 'Kwangpyeongok' was the strongest of all corn hybrids for lodging. The others except 'Kwangpyeongok' were similar to lodging. All corn hybrids were excellent to stay-green. Incidence of southern corn leaf blight (Bipolaris maydis) was low at all corn hybrids. '32P75' was $10.1 \%$, the most of all corn hybrids for incidence of BSDV (black streaked dwarf virus). 'Kwangpyeongok' and 'Gangdaok' were stronger than '32P75' for BSDV. Fresh yield of 'Kwangpyeongok' and 'Gangdaok' were the most of all corn hybrids as 74.85 and 76.68 ton/ha and 'P3394' was the least of all corn hybrids as 64.97 ton/ha. Dry matter yield as $18.83 \sim 21.92$ ton/ha and TDN yield as $12.73 \sim 14.52$ ton/ha were not significantly different among corn hybrids.
\end{abstract}

(Key words : Silage corn, Hybrid, Growth, Yield, Fresh matter, Dry matter, TDN)

\section{I. 서 론}

옥수수 국제곡물가격의 상승에 따른 배합사 료 및 조사료 수입가격이 급등하여 축산농가의 어려움이 가중되고 있어 사료비용 절감을 위해 옥수수 등 사료작물 재배가 늘어나는 추세이 다. 사료작물 중 사일리지용 옥수수는 단위 면 적당 건물생산성이 높을 뿐 아니라 영양가가 가장 높고 기호성이 좋아 우리나라와 같은 좁 은 면적에 어느 작물보다 수량과 품질이 우수
한 옥수수를 재배하는 것이 적합하다고 하였다 (김, 1986). 최근에는 청보리 및 호밀 등을 재 배한 후 하계에 사료작물 중 조사료 생산량이 가장 많으며 사료영양가치도 높은 사료용 옥수 수를 재배하려는 농가들이 늘어나고 있다. 국 내에서 재배되는 사일리지용 옥수수의 $70 \%$ 이 상이 P3394 등 수입종으로 농가에서 재배되고 있지만 광평옥 (문 등, 2001) 등 국내 육성 품 종은 2010년 총공급량 265톤중 78 톤으로 $29 \%$ 정도 밖에 재배되고 있지 않다. 그 동안 국산

\footnotetext{
${ }^{1}$ 국립식량과학원 (National Institute of Crop Science, RDA, Suwon 441-857, Korea)

2 천안연암대학 (Division of Animal Husbandry, Cheonan Yonam College, Cheonan 330-709, Korea)

${ }^{3}$ 계명문화대학 (Kmimyung College, Daegu 704-703, Korea)

Corresponding author: Beom-Young Son, National Institute of Crop Science, RDA, Suwon 441-857, Korea. Tel: +82-31-290-6758, Fax: +82-31-290-6742 E-mail: sonby@korea.kr
} 
사료용 옥수수는 수량이 적고 품질이 좋지 않 다는 인식이 축산농가에 팽배해 있었다. 하지 만 최근에는 국내 육성 품종인 광평옥 등은 기 존 수입 사일리지용 옥수수에 비해 쓰러짐에 강하고 후기녹체성이 2.5로 우수하며, 건물수량 도 ha당 19.48톤으로 많다 (문 등, 2001). 옥수 수는 지역, 기상, 토양 비옥도 및 토양수분 함 량에 따라 품종선택 및 재배방법이 다르고 이 에 따라 수량차이가 나타나므로 지역별로 적절 한 품종의 선택이 요구된다 (김, 1996). 지금까 지 사일리지용 옥수수에 대한 시험을 낙농 중 심지역인 중북부 내륙지역, 중북부 서해안지역, 중남부 서해안지역 및 해양성 기류가 어우러져 상습적인 안개와 강우가 많으며 적산온도와 일 조량이 부족한 해발 $800 \mathrm{~m}$ 가 되는 대관령지역 등에서 각각 수행하였으나 (김 등, 1997; 지 등, 2009; 임 등, 2001; 이 등, 2004) 다양한 지역에 서 같은 시기에 생육특성 및 생산성을 검토한 결과는 전무한 실정이다. 따라서 본 연구는 재 배지역에 따라 생육특성과 수량성이 다르게 나 타나기 때문에 국내 육성 및 도입 사일리지용 옥수수의 생육특성 및 수량성을 비교 검토하고 자 수행하였다.

\section{‥ 재료 및 방법}

본 시험은 작부체계 기후지대 구분에 따라 중북부 서해안지대에 속한 경기 화성, 중남부
서해안에 속한 충남 당진, 남부 서해안에 속한 전북 고창, 고랭지에 속한 강원 평창에서 2009 년에 수행하였다. 시험기간 중 기상은 Table 1 과 같이 사일리지용 옥수수를 재배해 오던 지 역으로 평년과 비슷한 기후조건이었다.

시험품종은 국내종인 광평옥, 강다옥과 국내 주요 수입종인 P3394, 32P75 등 4개 품종이었 다. 시비는 $\mathrm{ha}$ 당 질소 $(\mathrm{N}) 100 \mathrm{~kg}$, 인산 $\left(\mathrm{P}_{2} \mathrm{O}_{5}\right)$ $150 \mathrm{~kg}$, 칼리 $\left(\mathrm{K}_{2} 0\right) 150 \mathrm{~kg}$ 을 기비로 파종 전에 시용하였고, 질소 $(\mathrm{N}) 100 \mathrm{~kg}$ 을 파종 후 본엽이 7 8엽기 때 추비로 주었다. 퇴비는 ha당 20톤 을 시용하였고, 재식밀도, 파종기 및 수확기는 Table 2와 같다. 화성과 당진의 재식밀도는 휴 간 $70 \mathrm{~cm}$, 주간 $20 \mathrm{~cm}$ 로 ha당 66,667주를 심었 으며, 고창은 휴간 $60 \mathrm{~cm}$, 주간 $20 \mathrm{~cm}$ 로 $\mathrm{ha}$ 당 83,333 주, 평창은 휴간 $75 \mathrm{~cm}$, 주간 $16 \mathrm{~cm}$ 로 ha 당 83,333 주를 심었다. 파종은 그 지역특성에 따라 경기 화성과 충남 당진에서는 단작 파종 적기인 4월 18일, 4월 28일에 각각 하였으며, 전북 고창에서는 호맥을 수확하고 5 월 10 일에 하였고, 강원 평창에서는 파종적기인 5 월 5 일 에 하였다. 수확은 경기 화성에서 8월 10 일, 충 남 당진에서 8 월 24일, 전북 고창에서 8 월 14 일, 강원 평창에서 9월 4일에 하였다.

간장은 지면에서 웅수목까지의 길이를 측정 하고 착수고는 지면으로부터 최상단 암이삭이 달린 마디까지의 높이를 측정하였다. 도복과 후기녹체성의 조사범위는 1 9로 우수한 것을

Table 1. Mean temperature and precipitation during the experimental periods at different regions

\begin{tabular}{llrrrrrr}
\hline Region & Weather & April & May & June & July & Aug. & Sep. \\
\hline \hline \multirow{2}{*}{ Hwaseong } & Mean temperature $\left({ }^{\circ} \mathrm{C}\right)$ & 12.0 & 18.3 & 22.1 & 24.2 & 25.7 & 21.6 \\
& Precipitation $(\mathrm{mm})$ & 45.0 & 102.4 & 118.8 & 766.0 & 207.0 & 56.3 \\
\cline { 2 - 7 } Dangjin & Mean temperature $\left({ }^{\circ} \mathrm{C}\right)$ & 10.9 & 17.3 & 20.9 & 23.2 & 24.6 & 20.5 \\
& Precipitation $(\mathrm{mm})$ & 43.0 & 117.9 & 74.9 & 364.9 & 196.3 & 16.0 \\
\cline { 2 - 7 } Gochang & Mean temperature $\left({ }^{\circ} \mathrm{C}\right)$ & 11.9 & 18.3 & 22.4 & 24.6 & 25.5 & 21.5 \\
& Precipitation $(\mathrm{mm})$ & 55.0 & 116.3 & 175.7 & 475.9 & 207.7 & 59.5 \\
\cline { 2 - 7 } Pyeongchang & Mean temperature $\left({ }^{\circ} \mathrm{C}\right)$ & 7.0 & 13.7 & 17.0 & 18.6 & 18.3 & 14.5 \\
& Precipitation $(\mathrm{mm})$ & 50.4 & 74.9 & 105.2 & 517.8 & 189.9 & 33.0 \\
\hline
\end{tabular}


Table 2. Planting density, planting day and harvesting day at different regions

\begin{tabular}{lccc}
\hline Region & Planting density & Planting date & Harvesting date \\
\hline \hline Hwaseong & $70 \times 20 \mathrm{~cm}(66,667 / \mathrm{ha})$ & April 18 & Aug. 10 \\
Dangjin & $70 \times 20 \mathrm{~cm}(66,667 / \mathrm{ha})$ & April 28 & Aug. 24 \\
Gochang & $60 \times 20 \mathrm{~cm}(83,333 / \mathrm{ha})$ & May 10 & Aug. 14 \\
Pyeongchang & $75 \times 16 \mathrm{~cm}(83,333 / \mathrm{ha})$ & May 5 & Sep. 4 \\
\hline
\end{tabular}

1 , 불량한 것을 9 로 표시하였다. 깨씨무늬병 (Bipolaris maydis)의 조사범위는 0 9로 저항성 은 0 , 불량한 것을 9 로 표시하였다. 검은줄오갈 병 (BSDV)은 자연발생조건에서 조사하였다. 수 량조사는 가운데 2줄을 수확하여 암이삭과 경 엽으로 분리하여 생초수량을 조사하였으며 구 당 2주씩 샘플하여 경엽과 암이삭을 분리하여 $60{ }^{\circ} \mathrm{C}$ 의 열풍건조기에서 72 시간 건조 후 평량하 여 건물 함량을 산출하고 생초수량에 건물함량 을 곱하여 건물수량을 계산하였다. 건물률은 생초수량에 대한 건물수량 비율로 계산하였다. 가소화영양소총량 $(\mathrm{TDN})$ 수량은 Pioneer Hi-bred 사가 제시한 $\mathrm{TDN}($ Total Digestible Nutrients) $=$ (경엽건물수량 $\times 0.582)+($ 암이삭 건물수량 $\times 0.85$ ) 에 의하여 계산하였다 (Holland 등, 1990).

통계처리는 SAS 프로그램 (V. 9.1)의 PROC ANOVA procedure를 이용하여 Duncan의 다중 범위검정방법(Duncan's multiple range test,
$\mathrm{DMRT}$ )를 통해 평균값을 $5 \%$ 유의수준에서 비 교하였다.

\section{III. 결과 및 고찰}

1. 지역별 사일리지용 옥수수의 생육특성 및 수량

\section{(1) 화성지역}

화성지역의 사일리지용 옥수수 품종의 생육 특성은 Table 3 과 같다. 출사일수는 강다옥이 86 일로 가장 길었고, $\mathrm{P} 3394$ 가 81 일로 가장 짧 았으며, 광평옥과 $32 \mathrm{P} 75$ 는 83 일로 같았다. 모든 품종이 출사일수가 80 일을 넘었는데 이는 파종 기가 4월 18 일로 이 시기의 토양온도가 낮아 종자의 발아가 늦어진 결과라고 볼 수 있다. 간장은 $32 \mathrm{P} 75$ 가 $277 \mathrm{~cm}$ 로 가장 길었으며 광평 옥이 $261 \mathrm{~cm}$ 로 가장 짧았고 강다옥과 P3394는

Table 3. Agronomic characteristics of corn varieties at Hwaseong

\begin{tabular}{lccccccc}
\hline Variety & $\begin{array}{c}\text { Days to } \\
\text { silking } \\
\text { (days) }\end{array}$ & $\begin{array}{c}\text { Plant } \\
\text { height } \\
(\mathrm{cm})\end{array}$ & Ratio $)^{1)}$ & $\begin{array}{c}\text { Lodg- } \\
\text { ing } \\
(1 \sim 9)^{2)}\end{array}$ & $\begin{array}{c}\text { Stay } \\
\text { green } \\
(1 \sim 9)^{3)}\end{array}$ & $\begin{array}{c}\text { B. } \\
\text { maydis } \\
(0 \sim 9)\end{array}$ & $\begin{array}{c}\text { BSDV } \\
(\%)\end{array}$ \\
\hline \hline Kwangpyeongok & $83 \mathrm{~b}$ & $261 \mathrm{c}$ & $53 \mathrm{a}$ & $1 \mathrm{a}$ & $3 \mathrm{~b}$ & $1 \mathrm{a}$ & $0.5 \mathrm{a}$ \\
Gangdaok & $86 \mathrm{a}$ & $271 \mathrm{ab}$ & $56 \mathrm{a}$ & $2 \mathrm{a}$ & $3 \mathrm{~b}$ & $1 \mathrm{a}$ & $1.5 \mathrm{a}$ \\
P3394 & $81 \mathrm{c}$ & $262 \mathrm{bc}$ & $56 \mathrm{a}$ & $1 \mathrm{a}$ & $3 \mathrm{~b}$ & $1 \mathrm{a}$ & $2.0 \mathrm{a}$ \\
$32 \mathrm{P75}$ & $83 \mathrm{~b}$ & $277 \mathrm{a}$ & $56 \mathrm{a}$ & $2 \mathrm{a}$ & $4 \mathrm{a}$ & $1 \mathrm{a}$ & $0.5 \mathrm{a}$ \\
\hline
\end{tabular}

Ratio $^{1)}:$ Ear height ratio $=$ ear height/plant height $\times 100$.

Lodging $^{2)}$ and Stay-green ${ }^{3)}: 1=$ excellent (strong), $9=$ poor.

B. maydis (Southern leaf blight) : $0=$ excellent (strong), $9=$ poor.

BSDV : black streaked dwarf virus.

Ear ratio $(\%)^{4)}=$ Ear DM/total $\mathrm{DM} \times 100$.

Values within a column followed by the same letter are not significantly different at the 0.05 level by LSD test. 
비슷하였다. 착수고율은 53 56으로 비슷한 경 향을 나타내었다. 도복은 1 2로 품종간 차이가 없었다. 후기녹체성은 $32 \mathrm{P} 75$ 를 제외한 품종들 은 3으로 우수하였다. 우리나라에서 사료영양 가를 저해요인으로 가장 많이 발생하는 옥수수 병중의 하나인 깨씨무늬병은 시험품종 모두 발 병률이 낮았으며 품종간 차이는 없었다. 검은 줄오갈병은 중부지역보다 남부지역이 심하지만 요즘은 중부지역까지 확산되고 있다고 하였다 (이 등, 1987 ; 이 등, 1988). 본 시험의 검은줄 오갈병 감염정도는 $0.5 \sim 2.0 \%$ 로 낮았으며 품종 간 차이는 없었다. 화성지역이 당진 및 고창지 역보다 발생률이 낮은 경향을 보였는데 이러한 결과는 이 등 (1988)이 검은줄오갈병의 발병률 이 중북부 서해안 지역이 남부지역보다 낮다는 보고와 비슷한 경향을 보였다.

사일리지용 옥수수 품종의 암이삭 비율, 이 삭길이 및 수량성을 비교해 보면 Table 4와 같 다. 사일리지옥수수에서 가장 중요한 부분이 암이삭이며, 암이삭비율이 높으면 사일리지의 품질이 높아져 사료가치 증진에 유리하다고 하 여 이삭비율이 강조되고 있다(Phipps \& Wilkinson, 1985, 김 등, 1996). 암이삭 비율은 광평옥과 강다옥이 각각 $39 \%, 37 \%$ 로 $\mathrm{P} 3394$ 와 $32 \mathrm{P} 75$ 보다 낮았다. 따라서 국내 사일리지 옥 수수의 사료가치를 향상시키기 위하여 이삭비
율이 $50 \%$ 이상 되는 품종개발이 요구된다. 이 삭길이는 광평옥이 $18 \mathrm{~cm}$ 로 가장 짧았으며 다 른 품종들은 이삭길이가 비슷하였다. 사일리지 용 옥수수의 생체수량은 광평옥 (문 등, 2001) 과 강다옥(Son 등, 2006)이 각각 ha당 80톤, 78.57 톤으로 $\mathrm{P} 3394$ 와 $32 \mathrm{P} 75$ 보다 높았다. 건물 수량은 광평옥과 강다옥이 각각 $\mathrm{ha}$ 당 23.06톤, 26.01톤으로 P3394와 32P75 보다 많았다. TDN 수량은 광평옥과 강다옥이 각각 $\mathrm{ha}$ 당 15.55 톤, 17.43 톤으로 $\mathrm{P} 3394$ 와 $32 \mathrm{P} 75$ 보다 많았다. 국내 품종의 암 이삭 부분의 건물중이 수입종보다 낮았지만, 국내 품종들은 이삭부분을 제외한 줄기와 엽부분의 건물중은 수입종 보다 상대적 으로 높아 전체적인 건물수량이 높은 것으로 나타났다.

\section{(2) 당진지역}

당진지역의 사일리지용 옥수수 품종의 생육 특성은 Table 5와 같다. 출사일수는 강다옥이 78 일로 가장 길었고, $\mathrm{P} 3394$ 가 72 일로 가장 짧 았으며, 광평옥과 $32 \mathrm{P} 75$ 는 같았다. 모든 품종이 출사일수가 70 일 범위였는데 이는 파종기가 4 월 28 일로 화성보다 10 일 늦게 파종하였지만 적산온도가 높았기 때문에 종자의 발아가 빨라 진 결과라고 볼 수 있다. 간장은 $219 \sim 241 \mathrm{~cm}$, 착수고율은 $52 \sim 56 \%$ 로 품종간 차이는 없었다.

Table 4. Ear rate, ear length, fresh matter yield, dry matter yield and total digestible nutrients (TDN) of corn varieties at Hwaseong

\begin{tabular}{lcccccc}
\hline \multirow{2}{*}{ Variety } & \multirow{2}{*}{$\begin{array}{c}\text { Ear } \\
\text { rate } \\
(\%)\end{array}$} & $\begin{array}{c}\text { Ear } \\
\text { length } \\
(\mathrm{cm})\end{array}$ & $\begin{array}{c}\text { Fresh } \\
\text { matter }\end{array}$ & $\begin{array}{c}\text { Dry } \\
\text { matter }\end{array}$ & $\begin{array}{c}\text { YMR } \\
(\%)\end{array}$ & TDN \\
\hline \hline Kwangpyeongok & $39 \mathrm{~b}$ & $18 \mathrm{~b}$ & $80.00 \mathrm{a}$ & $23.06 \mathrm{ab}$ & 28.8 & $15.55 \mathrm{ab}$ \\
Gangdaok & $37 \mathrm{~b}$ & $22 \mathrm{a}$ & $78.57 \mathrm{a}$ & $26.01 \mathrm{a}$ & 33.1 & $17.43 \mathrm{a}$ \\
P3394 & $42 \mathrm{a}$ & $22 \mathrm{a}$ & $64.28 \mathrm{~b}$ & $21.42 \mathrm{~b}$ & 33.3 & $14.64 \mathrm{~b}$ \\
$32 \mathrm{P} 75$ & $45 \mathrm{a}$ & $21 \mathrm{a}$ & $68.57 \mathrm{~b}$ & $21.39 \mathrm{~b}$ & 31.2 & $14.73 \mathrm{~b}$ \\
\hline
\end{tabular}

$\mathrm{DMR}^{1)}$ : Dry matter rate.

Values within a column followed by the same letter are not significantly different at the 0.05 level by LSD test. 
Table 5. Agronomic characteristics of corn varieties at Dangjin

\begin{tabular}{lccccccc}
\hline \multicolumn{1}{c}{ Variety } & $\begin{array}{c}\text { Days to } \\
\text { silking } \\
(\text { days })\end{array}$ & $\begin{array}{c}\text { Plant } \\
\text { height } \\
(\mathrm{cm})\end{array}$ & Ratio $^{1)}$ & $\begin{array}{c}\text { Lodg- } \\
\text { ing } \\
(1 \sim 9)^{2)}\end{array}$ & $\begin{array}{c}\text { Stay } \\
\text { green } \\
(1 \sim 9)^{3)}\end{array}$ & $\begin{array}{c}\text { B. } \\
\text { maydis } \\
(0 \sim 9)\end{array}$ & $\begin{array}{c}\text { BSDV } \\
(\%)\end{array}$ \\
\hline \hline Kwangpyeongok & $75 \mathrm{~b}$ & $241 \mathrm{a}$ & $52 \mathrm{a}$ & $1 \mathrm{c}$ & $3 \mathrm{~b}$ & $1 \mathrm{a}$ & $3 \mathrm{~b}$ \\
Gangdaok & $78 \mathrm{a}$ & $236 \mathrm{a}$ & $53 \mathrm{a}$ & $3 \mathrm{~b}$ & $3 \mathrm{~b}$ & $1 \mathrm{a}$ & $3 \mathrm{~b}$ \\
P3394 & $72 \mathrm{c}$ & $224 \mathrm{a}$ & $53 \mathrm{a}$ & $3 \mathrm{~b}$ & $4 \mathrm{a}$ & $1 \mathrm{a}$ & $3 \mathrm{~b}$ \\
$32 \mathrm{P75}$ & $75 \mathrm{~b}$ & $219 \mathrm{a}$ & $56 \mathrm{a}$ & $5 \mathrm{a}$ & $3 \mathrm{~b}$ & $1 \mathrm{a}$ & $6 \mathrm{a}$ \\
\hline
\end{tabular}

Ratio $^{1)}$ : Ear height ratio $=$ ear height/plant height $\times 100$.

Lodging $^{2)}$ and Stay-green ${ }^{3)}: 1=$ excellent(strong), $9=$ poor.

B. maydis (Southern leaf blight) : $0=$ excellent(strong), $9=$ poor.

BSDV : black streaked dwarf virus.

Ear ratio $(\%)^{4)}=$ Ear DM/total $\mathrm{DM} \times 100$.

Values within a column followed by the same letter are not significantly different at the 0.05 level by LSD test.

도복은 광평옥이 1 로 가장 강하였고 $32 \mathrm{P} 75$ 가 5 로 가장 약하였다. 후기녹체성은 P3394를 제외 한 품종들은 3으로 후기녹체성이 우수하였다. 깨씨무늬병은 시험품종 모두 1 로 발병률이 낮 았으며 품종간 차이는 없었다. 검은줄오갈병은 $32 \mathrm{P} 75$ 가 $6 \%$ 로 가장 많았으며 광평옥과 강다옥 이 각각 $3 \%$ 로 $32 \mathrm{P} 75$ 보다 상대적으로 강한 것 으로 나타났다.

당진지역의 사일리지용 옥수수 품종의 암이 삭 비율, 이삭길이 및 수량성을 비교해 보면 Table 6과 같다. 암이삭 비율은 광평옥과 강다 옥이 각각 $52 \%, 55 \%$ 로 상대적으로 다른 지역 보다 높은 것으로 나타났다. 이삭길이는 강다 옥과 $32 \mathrm{P} 75$ 가 $22 \mathrm{~cm}$ 로 가장 길었으며 광평옥이
$19 \mathrm{~cm}$ 로 가장 짧았다. 사일리지용 옥수수의 생체 수량은 광평옥이 ha당 77.14톤으로 가장 많았고 $\mathrm{P} 3394$ 가 ha당 62.85 톤으로 가장 적었다. 건물수 량은 ha당 19.91톤 23.35톤, TDN 수량은 ha당 14.28톤 16.63톤으로 품종간 차이는 없었다.

\section{(3) 고창지역}

고창지역은 이모작 작부체계가 가능한 지역 으로 동계에는 이탈리안 라이그라스(IRG) 재배 하고, 하계에는 사일리지용 옥수수 재배하여 단위면적당 자급사료 생산량을 증대가 가능한 지역으로 본 시험에서는 5 월 10 일에 파종하여 국내 사일리지용 옥수수 재배 가능성을 검토하 였다. 이 지역의 사일리지옥수수 품종의 생육

Table 6. Ear rate, ear length, fresh matter yield, dry matter yield and total digestible nutrients (TDN) of corn varieties at Dangjin

\begin{tabular}{|c|c|c|c|c|c|c|}
\hline \multirow[b]{2}{*}{ Variety } & \multirow{2}{*}{$\begin{array}{l}\text { Ear } \\
\text { rate } \\
(\%) \\
\end{array}$} & \multirow{2}{*}{$\begin{array}{c}\text { Ear } \\
\text { length } \\
(\mathrm{cm})\end{array}$} & \multicolumn{4}{|c|}{ Yield (ton/ha) } \\
\hline & & & $\begin{array}{l}\text { Fresh } \\
\text { matter }\end{array}$ & $\begin{array}{c}\text { Dry } \\
\text { matter }\end{array}$ & $\begin{array}{c}\mathrm{DMR}^{1)} \\
(\%)\end{array}$ & TDN \\
\hline Kwangpyeongok & $52 \mathrm{a}$ & $19 \mathrm{c}$ & $77.14 \mathrm{a}$ & $20.73 a$ & 26.9 & $14.64 \mathrm{a}$ \\
\hline Gangdaok & $55 \mathrm{a}$ & $22 \mathrm{a}$ & $72.85 \mathrm{ab}$ & $23.35 \mathrm{a}$ & 32.1 & $16.63 \mathrm{a}$ \\
\hline P3394 & $58 \mathrm{a}$ & $21 b$ & $62.85 \mathrm{~b}$ & $20.86 \mathrm{a}$ & 33.2 & $15.02 \mathrm{a}$ \\
\hline $32 \mathrm{P} 75$ & $57 \mathrm{a}$ & $22 \mathrm{a}$ & $68.57 \mathrm{ab}$ & $19.91 \mathrm{a}$ & 29.0 & $14.28 \mathrm{a}$ \\
\hline
\end{tabular}

$\mathrm{DMR}^{1)}$ : Dry matter rate.

Values within a column followed by the same letter are not significantly different at the 0.05 level by LSD test. 
특성을 비교해 보면 Table 7과 같다.

출사일수는 강다옥이 69일로 가장 길었고, $\mathrm{P} 3394$ 가 62일로 가장 짧았으며, 광평옥과 $32 \mathrm{P} 75$ 는 65 일로 같았다. 모든 품종이 출사일수가 60 일 범위였는데 이는 파종기가 다른 지역보다 늦게 파종하였지만 5 월의 기상 및 토양 온도가 4월보다 높아 종자 발아 및 초기 생육이 빨라 진 결과라고 볼 수 있다. 간장은 광평옥과 강 다옥이 각각 $239 \mathrm{~cm}, 234 \mathrm{~cm}$ 로 가장 길었으며 $32 \mathrm{P} 75$ 가 $206 \mathrm{~cm}$ 로 가장 짧았다. 착수고율은 강 다옥이 $59 \%$ 로 가장 높았으며 다른 품종은 52 $\sim 55 \%$ 범위로 차이는 없었다. 도복은 모든 품 종들이 3 이었으며 품종간 차이는 없었다. 후기
녹체성은 모든 품종들이 3 이었으며 품종간 차 이는 없었다. 깨씨무늬병은 P3394를 제외한 시 험품종 모두 발병률이 낮았으며 품종간 차이는 없었다. 검은줄오갈병은 $32 \mathrm{P} 75$ 가 $10 \%$ 로 가장 많았으며, 나머지 품종들은 2 3\%로 상대적으 로 $32 \mathrm{P} 75$ 보다 강한 것으로 나타났다.

고창지역의 사일리지용 옥수수 품종의 암이 삭 비율, 이삭길이 및 수량성을 비교해 보면 Table 8과 같다. 암이삭 비율은 30 41\% 범위로 품종들 평균간 차이는 없었으며 단작지역인 당 진지역보다 생육기간이 상대적으로 짧아 암이 삭 비율이 낮은 것으로 사료된다. 이삭길이는 $32 \mathrm{P} 75$ 가 $21 \mathrm{~cm}$ 로 가장 길었으며 광평옥이 17

Table 7. Agronomic characteristics of corn varieties at Gochang

\begin{tabular}{lccccccc}
\hline Variety & $\begin{array}{c}\text { Days to } \\
\text { silking } \\
(\text { days })\end{array}$ & $\begin{array}{c}\text { Plant } \\
\text { height } \\
(\mathrm{cm})\end{array}$ & Ratio $^{1)}$ & $\begin{array}{c}\text { Lodg- } \\
\text { ing } \\
(1 \sim 9)^{2)}\end{array}$ & $\begin{array}{c}\text { Stay } \\
\text { green } \\
(1 \sim 9)^{3}\end{array}$ & $\begin{array}{c}\text { B. } \\
\text { maydis } \\
(0 \sim 9)\end{array}$ & $\begin{array}{c}\text { BSDV } \\
(\%)\end{array}$ \\
\hline \hline Kwangpyeongok & $65 \mathrm{~b}$ & $239 \mathrm{a}$ & $55 \mathrm{~b}$ & $3 \mathrm{a}$ & $3 \mathrm{a}$ & $1 \mathrm{~b}$ & $2 \mathrm{c}$ \\
Gangdaok & $69 \mathrm{a}$ & $234 \mathrm{a}$ & $59 \mathrm{a}$ & $3 \mathrm{a}$ & $3 \mathrm{a}$ & $1 \mathrm{~b}$ & $2 \mathrm{c}$ \\
P3394 & $62 \mathrm{c}$ & $206 \mathrm{~b}$ & $55 \mathrm{~b}$ & $3 \mathrm{a}$ & $3 \mathrm{a}$ & $3 \mathrm{a}$ & $3 \mathrm{~b}$ \\
32 P75 & $65 \mathrm{~b}$ & $193 \mathrm{c}$ & $52 \mathrm{~b}$ & $3 \mathrm{a}$ & $3 \mathrm{a}$ & $1 \mathrm{~b}$ & $10 \mathrm{a}$ \\
\hline
\end{tabular}

Ratio $^{1)}:$ Ear height ratio $=$ ear height/plant height $\times 100$.

Lodging $^{2)}$ and Stay-green ${ }^{3)}: 1=$ excellent (strong), $9=$ poor.

B. maydis (Southern leaf blight) : $0=$ excellent (strong), $9=$ poor.

BSDV : black streaked dwarf virus.

Ear ratio $(\%)^{4)}=$ Ear DM/total $\mathrm{DM} \times 100$.

Values within a column followed by the same letter are not significantly different at the 0.05 level by LSD test.

Table 8. Ear rate, ear length, fresh matter yield, dry matter yield and total digestible nutrients (TDN) of corn varieties at Gochang

\begin{tabular}{|c|c|c|c|c|c|c|}
\hline \multirow[b]{2}{*}{ Variety } & \multirow{2}{*}{$\begin{array}{l}\text { Ear } \\
\text { rate } \\
(\%)\end{array}$} & \multirow{2}{*}{$\begin{array}{l}\text { Ear } \\
\text { length } \\
(\mathrm{cm})\end{array}$} & \multicolumn{4}{|c|}{ Yield (ton/ha) } \\
\hline & & & $\begin{array}{l}\text { Fresh } \\
\text { matter }\end{array}$ & $\begin{array}{c}\text { Dry } \\
\text { matter }\end{array}$ & $\begin{array}{c}\mathrm{DMR}^{1)} \\
(\%)\end{array}$ & TDN \\
\hline Kwangpyeongok & $30 \mathrm{a}$ & $17 \mathrm{~b}$ & $67.67 \mathrm{ab}$ & $19.10 \mathrm{a}$ & 28.2 & $12.46 \mathrm{a}$ \\
\hline Gangdaok & $33 a$ & $19 \mathrm{ab}$ & $76.34 \mathrm{a}$ & $21.49 \mathrm{a}$ & 28.2 & $14.18 \mathrm{a}$ \\
\hline P3394 & $41 \mathrm{a}$ & $18 \mathrm{ab}$ & $64.20 \mathrm{~b}$ & $20.86 a$ & 32.5 & $14.14 \mathrm{a}$ \\
\hline $32 \mathrm{P} 75$ & $34 a$ & $21 \mathrm{a}$ & $67.67 \mathrm{ab}$ & $19.75 \mathrm{a}$ & 29.2 & $13.11 \mathrm{a}$ \\
\hline
\end{tabular}

$\mathrm{DMR}^{1)}$ : Dry matter rate.

Values within a column followed by the same letter are not significantly different at the 0.05 level by LSD test. 
$\mathrm{cm}$ 로 가장 짧았다. 사일리지용 옥수수의 생체 수량은 강다옥이 ha당 76.34톤으로 가장 많았 고, $\mathrm{P} 3394$ 가 ha당 64.2톤으로 가장 적었다. 건 물수량은 ha당 19.1톤 21.49톤, TDN 수량은 ha 당 12.46톤 14.18톤으로 품종간 차이는 없었다. 국내 사일리지용 옥수수 광평옥과 강다옥에 대 한 고창지역의 생육과 수량 반응을 볼 때 화성 과 당진지역에 비하여 생육 및 수량이 크게 떨 어지지 않아 동계사료작물 후작으로 재배 가능 한 품종이라 볼 수 있다.

\section{(4) 평창지역}

평창 대관령지역은 해발 $800 \mathrm{~m}$ 가 되는 고원 지대로서 만상일이 5월 16일이고 초상일은 9월 28 일경이다. 따라서 국내 육성 사일리지용 옥 수수 품종을 평지보다 생육기간이 짧은 평창 대관령지역에서 환경적응성 및 수량성을 평가 하기 위하여 시험을 실시하였다. 평창지역의 사일리지용 옥수수 품종의 생육특성을 비교해 보면 Table 9와 같다. 출사일수는 강다옥이 104 일로 가장 길었고, $\mathrm{P} 3394$ 와 32P75가 97일로 가 장 짧았다. 모든 품종이 출사일수가 97일 104 일 범위였는데 화성 및 당진지역보다 출사일수 가 길었다. 이는 대관령지역이 고원지대로서 서쪽에서 오는 한랭한 북서풍과 동해 쪽에서
오는 해양성 기후가 만나 상습적인 안개와 강 우로 적산온도와 일조량이 부족하여 생육이 지 연된 결과라고 볼 수 있다. 임 등 (2001)은 출 사일수가 79 89일 소요되었다고 하였는데, 이 는 파종기가 본 시험보다 늦었기 때문이며 출 사기는 비슷한 경향이었다. 간장은 $32 \mathrm{P} 75$ 가 $274 \mathrm{~cm}$ 로 가장 길었으며, 다른 품종들은 250 $252 \mathrm{~cm}$ 범위로 비슷하였다. 착수고율은 강다옥 이 $49 \%$ 로 가장 높았으며 광평옥과 $\mathrm{P} 3394$ 가 $46 \%$ 로 가장 낮았다. 도복은 모든 품종이 1로 평균간 차이는 없었다. 후기녹체성은 모든 품 종이 3 으로 품종간 차이는 없었다. 깨씨무늬병 과 검은줄오갈병 등은 품종간 차이는 없었다. 평창지역은 모든 품종에서 검은줄오갈병이 발 생하지 않았다.

평창지역의 사일리지용 옥수수 품종의 암이 삭 비율, 이삭길이 및 수량성을 비교해 보면 Table 10과 같다. 암이삭 비율은 광평옥이 34 $\%$, 강다옥이 $29 \%$ 이었지만, 품종간 차이는 없 었다. 임 등 (2001)에 의하면 출사기가 빠른 품 종들은 암이삭 비율이 $46 \%$ 이상 높고, 출사기 가 늦은 품종은 $40 \%$ 이하였는데, 평창지역에서 는 출사기가 늦은 중만생종인 광평옥과 강다옥 보다 출사기 및 숙기가 빠른 조생종이나 중생 종이 적합할 것으로 사료된다. 이삭길이는 강

Table 9. Agronomic characteristics of corn varieties at Pyeongchang

\begin{tabular}{lccccccc}
\hline Variety & $\begin{array}{c}\text { Days to } \\
\text { silking } \\
\text { (days) }\end{array}$ & $\begin{array}{c}\text { Plant } \\
\text { height } \\
(\mathrm{cm})\end{array}$ & Ratio $^{1)}$ & $\begin{array}{c}\text { Lodg- } \\
\text { ing } \\
(1 \sim 9)^{2)}\end{array}$ & $\begin{array}{c}\text { Stay } \\
\text { green } \\
\left.(1 \sim 9)^{3}\right)\end{array}$ & $\begin{array}{c}\text { B. } \\
\text { maydis } \\
(0 \sim 9)\end{array}$ & $\begin{array}{c}\text { BSDV } \\
(\%)\end{array}$ \\
\hline \hline Kwangpyeongok & $102 \mathrm{~b}$ & $252 \mathrm{~b}$ & $46 \mathrm{c}$ & $1 \mathrm{a}$ & $3 \mathrm{a}$ & $1 \mathrm{a}$ & $0 \mathrm{a}$ \\
Gangdaok & $104 \mathrm{a}$ & $251 \mathrm{~b}$ & $49 \mathrm{a}$ & $1 \mathrm{a}$ & $3 \mathrm{a}$ & $1 \mathrm{a}$ & $0 \mathrm{a}$ \\
P3394 & $97 \mathrm{c}$ & $250 \mathrm{~b}$ & $46 \mathrm{c}$ & $1 \mathrm{a}$ & $3 \mathrm{a}$ & $1 \mathrm{a}$ & $0 \mathrm{a}$ \\
32 P75 & $97 \mathrm{c}$ & $274 \mathrm{a}$ & $47 \mathrm{~b}$ & $1 \mathrm{a}$ & $3 \mathrm{a}$ & $1 \mathrm{a}$ & $0 \mathrm{a}$ \\
\hline
\end{tabular}

Ratio $^{1)}:$ Ear height ratio $=$ ear height/plant height $\times 100$.

Lodging $^{2)}$ and Stay-green ${ }^{3)}: 1=$ excellent(strong), $9=$ poor.

B. maydis (Southern leaf blight) : $0=$ excellent(strong), $9=$ poor.

BSDV : black streaked dwarf virus.

Ear ratio $(\%)^{4)}=$ Ear DM/total $\mathrm{DM} \times 100$.

Values within a column followed by the same letter are not significantly different at the 0.05 level by LSD test. 
Table 10. Ear rate, ear length, fresh matter yield, dry matter yield and total digestible nutrients (TDN) of corn varieties at Pyeongchang

\begin{tabular}{|c|c|c|c|c|c|c|}
\hline \multirow[b]{2}{*}{ Variety } & \multirow{2}{*}{$\begin{array}{l}\text { Ear } \\
\text { rate } \\
(\%)\end{array}$} & \multirow{2}{*}{$\begin{array}{l}\text { Ear } \\
\text { length } \\
(\mathrm{cm})\end{array}$} & \multicolumn{4}{|c|}{ Yield (ton/ha) } \\
\hline & & & $\begin{array}{l}\text { Fresh } \\
\text { matter }\end{array}$ & $\begin{array}{c}\text { Dry } \\
\text { matter }\end{array}$ & $\begin{array}{c}\mathrm{DMR}^{1)} \\
(\%)\end{array}$ & TDN \\
\hline Kwangpyeongok & $34 \mathrm{a}$ & $16 \mathrm{~b}$ & 74.61ab & $14.14 \mathrm{~b}$ & 19.0 & $8.26 \mathrm{~b}$ \\
\hline Gangdaok & $29 a$ & $19 \mathrm{a}$ & $78.94 \mathrm{a}$ & $16.84 \mathrm{a}$ & 21.3 & $9.85 \mathrm{a}$ \\
\hline P3394 & $44 \mathrm{a}$ & $17 \mathrm{~b}$ & $68.53 b$ & $12.21 \mathrm{c}$ & 17.8 & $7.14 \mathrm{c}$ \\
\hline $32 \mathrm{P} 75$ & $30 \mathrm{a}$ & $17 \mathrm{~b}$ & $74.61 \mathrm{ab}$ & $17.00 \mathrm{a}$ & 22.8 & $9.93 \mathrm{a}$ \\
\hline
\end{tabular}

$\mathrm{DMR}^{1)}$ : Dry matter rate.

Values within a column followed by the same letter are not significantly different at the 0.05 level by LSD test.

다옥이 $19 \mathrm{~cm}$ 로 가장 길었으며, 다른 품종들은 $16 \sim 17 \mathrm{~cm}$ 범위로 품종간 차이는 없었다. 사일 리지용 옥수수의 생체수량은 광평옥, 강다옥 및 32P75가 ha당 74.61톤 78.94톤 범위로 비슷 하였으며, P3394가 ha당 68.53톤으로 가장 적었 다. 건물수량은 강다옥과 $32 \mathrm{P} 75$ 가 각각 $\mathrm{ha}$ 당 16.84 톤, 17 톤으로 가장 많았으며, P3394가 ha 당 12.21 톤으로 가장 적었다. $\mathrm{TDN}$ 수량은 강 다옥과 $32 \mathrm{P} 75$ 가 각각 $\mathrm{ha}$ 당 9.85톤, 9.93톤으로 가장 많았으며, $\mathrm{P} 3394$ 가 $\mathrm{ha}$ 당 7.14톤으로 가장 적었다. 평창지역은 서리 내리는 시기를 고려 하여 수확적기보다 일찍 수확을 하였다. 생체 수량은 이삭이 나온 후 평균 22일경 수확을 하 여 생체수량이 최대인 시기에 수확을 하여 수 량감소가 없었으나, 건물수량과 $\mathrm{TDN}$ 수량이 아직 증가하고 있는 시기에 수확을 하였기 때 문에 건물수량과 $\mathrm{TDN}$ 수량이 낮게 나타났다. 또한 이 등 (2004)은 5월 10 일 파종기에서 연 차 간의 건물수량 차이는 대관령과 같은 고령 지에서는 기상이 해마다 달라 너무 이른 파종 은 늦추위로 인한 초기생육의 부진으로 수량 감소를 초래 할 수 있다고 하였는데, 본 시험 의 건물수량 및 $\mathrm{TDN}$ 수량감소는 늦추위로 인 한 초기생육부진에 의한 것보다 수확기를 앞당 겼기 때문이라 사료된다.

\section{2. 사일리지용 옥수수의 생육특성 및 수량}

사일리지용 옥수수 품종의 생육특성을 종합 적으로 비교해 보면 Table 11과 같다. 출사일수 는 강다옥이 84 일로 가장 길었고, $\mathrm{P} 3394$ 가 78 일로 가장 짧았으며, 광평옥과 $32 \mathrm{P} 75$ 는 비슷하 였다. 간장과 착수고율은 품종간 차이는 없었 다. 도복은 광평옥이 가장 강하였고, 다른 품종 들은 비슷하였다. 후기녹체성은 품종간 차이는 없었다. 깨씨무늬병은 시험품종 모두 발병률이 낮았다. 검은줄오갈병은 $32 \mathrm{P} 75$ 가 $10.1 \%$ 로 가장 많았으며 광평옥과 강다옥이 $32 \mathrm{P} 75$ 보다 상대 적으로 강한 것으로 나타났다.

사일리지용 옥수수 품종의 암이삭 비율, 이 삭길이 및 수량성을 비교해 보면 Table 12와 같다. 암이삭 비율은 품종간 차이는 없었다. 이 삭길이는 강다옥과 $32 \mathrm{P} 75$ 가 각각 $21 \mathrm{~cm}, 20 \mathrm{~cm}$ 로 가장 길었으며 광평옥과 P3394는 비슷하였 다. 사일리지용 옥수수의 생체수량은 광평옥과 강다옥이 각각 ha당 74.85 톤, 76.68 톤으로 가장 많았고 P3394가 ha당 64.97톤으로 가장 적었다. 건물수량은 $\mathrm{ha}$ 당 18.83 톤 21.92톤, $\mathrm{TDN}$ 수량은 ha당 12.73톤 14.52톤 범위로 품종간 차이는 없 었다.

따라서 본 시험에서 광평옥과 강다옥은 지역 간의 반응은 달랐지만 대체로 생육특성은 수입 
Table 11. Agronomic characteristics of corn varieties at 4 regions

\begin{tabular}{lccccccc}
\hline \multicolumn{1}{c}{ Variety } & $\begin{array}{c}\text { Days to } \\
\text { silking } \\
(\text { days })\end{array}$ & $\begin{array}{c}\text { Plant } \\
\text { height } \\
(\mathrm{cm})\end{array}$ & Ratio $^{1)}$ & $\begin{array}{c}\text { Lodg- } \\
\text { ing } \\
(1 \sim 9)^{2)}\end{array}$ & $\begin{array}{c}\text { Stay } \\
\text { green } \\
(1 \sim 9)^{3)}\end{array}$ & $\begin{array}{c}B . \\
\text { maydis } \\
(0 \sim 9)\end{array}$ & $\begin{array}{c}\text { BSDV } \\
(\%)\end{array}$ \\
\hline \hline Kwangpyeongok & $81 \mathrm{~b}$ & $248 \mathrm{a}$ & $51 \mathrm{a}$ & $1.5 \mathrm{~b}$ & $3.0 \mathrm{a}$ & $1.0 \mathrm{~b}$ & $1.4 \mathrm{~b}$ \\
Gangdaok & $84 \mathrm{a}$ & $246 \mathrm{a}$ & $54 \mathrm{a}$ & $2.3 \mathrm{ab}$ & $3.0 \mathrm{a}$ & $1.0 \mathrm{~b}$ & $1.6 \mathrm{~b}$ \\
P3394 & $78 \mathrm{c}$ & $235 \mathrm{a}$ & $53 \mathrm{a}$ & $2.0 \mathrm{ab}$ & $3.3 \mathrm{a}$ & $1.5 \mathrm{a}$ & $2.0 \mathrm{~b}$ \\
$32 \mathrm{P} 75$ & $80 \mathrm{~b}$ & $241 \mathrm{a}$ & $52 \mathrm{a}$ & $2.8 \mathrm{a}$ & $3.3 \mathrm{a}$ & $1.0 \mathrm{~b}$ & $4.1 \mathrm{a}$ \\
\hline
\end{tabular}

Ratio $^{1)}:$ Ear height ratio $=$ ear height/plant height $\times 100$.

Lodging $^{2)}$ and Stay-green ${ }^{3)}: 1=$ excellent(strong), $9=$ poor.

B. maydis (Southern leaf blight) : $0=$ excellent(strong), $9=$ poor

BSDV : black streaked dwarf virus.

Ear ratio $(\%)^{4)}=$ Ear DM/total $\mathrm{DM} \times 100$.

Values within a column followed by the same letter are not significantly different at the 0.05 level by LSD test.

Table 12. Ear rate, ear length, fresh matter yield, dry matter yield and total digestible nutrients (TDN) of corn varieties at 4 regions

\begin{tabular}{|c|c|c|c|c|c|c|}
\hline \multirow[b]{2}{*}{ Variety } & \multirow{2}{*}{$\begin{array}{l}\text { Ear } \\
\text { rate } \\
(\%)\end{array}$} & \multirow{2}{*}{$\begin{array}{l}\text { Ear } \\
\text { length } \\
(\mathrm{cm})\end{array}$} & \multicolumn{4}{|c|}{ Yield (ton/ha) } \\
\hline & & & $\begin{array}{l}\text { Fresh } \\
\text { matter }\end{array}$ & $\begin{array}{c}\text { Dry } \\
\text { matter }\end{array}$ & $\begin{array}{c}\mathrm{DMR}^{1)} \\
(\%)\end{array}$ & TDN \\
\hline Kwangpyeongok & $39 a$ & $18 \mathrm{~b}$ & $74.85 \mathrm{a}$ & $19.26 \mathrm{a}$ & 25.7 & $12.73 \mathrm{a}$ \\
\hline Gangdaok & $38 \mathrm{a}$ & $21 \mathrm{a}$ & $76.68 \mathrm{a}$ & $21.92 \mathrm{a}$ & 28.6 & $14.52 \mathrm{a}$ \\
\hline P3394 & $46 a$ & $19 \mathrm{ab}$ & $64.97 \mathrm{c}$ & $18.83 \mathrm{a}$ & 29.0 & $12.73 a$ \\
\hline $32 \mathrm{P} 75$ & $41 \mathrm{a}$ & $20 \mathrm{a}$ & $69.85 b$ & $19.51 \mathrm{a}$ & 27.9 & $13.01 \mathrm{a}$ \\
\hline
\end{tabular}

$\mathrm{DMR}^{1)}$ : Dry matter rate.

Values within a column followed by the same letter are not significantly different at the 0.05 level by LSD test.

종인 P3394와 32P75과 비슷하였으나 검은줄오 갈병의 경우 수입종 보다 강하고, 수량성에서 도 국내 육성 사일리지용 옥수수인 광평옥과 강다옥이 수입종과 대등하여 국산 품종보다 가 격이 비싼 수입종에 경쟁력이 있는 것으로 생 각된다.

$$
\text { IV. 요 약 }
$$

본 연구는 재배지역별 국내 육성 사일리지용 옥수수의 생육특성 및 수량성을 비교하고자 중 북부 서해안지대에 속한 경기 화성, 중남부 서
해안에 속한 충남 당진, 남부 서해안에 속한 전북 고창, 고랭지에 속한 강원 평창에서 2009 년에 수행하였다. 시험품종은 국내종인 광평옥, 강다옥과 국내 주요 수입종인 P3394, 32P75 등 4 개 품종이었다. 화성지역의 모든 품종의 출사 일수가 80 일이 넘었으며 생체수량, 건물수량 및 TDN 수량은 광평옥과 강다옥이 P3394와 $32 \mathrm{P} 75$ 보다 많았다. 당진지역의 모든 품종의 출사일수가 70 일 범위였으며 생체수량은 광평 옥이 가장 많았으며 건물수량 및 $\mathrm{TDN}$ 수량은 품종간 차이가 없었다. 고창지역의 모든 품종 의 출사일수가 60 일 범위였으며 생체수량은 강 
다옥이 가장 많았으며 건물수량 및 $\mathrm{TDN}$ 수량 은 품종간 차이가 없었다. 평창지역의 모든 품 종의 출사일수가 97 104일 범위였으며 생체수 량은 P3394가 가장 적었으며 건물수량 및 $\mathrm{TDN}$ 수량은 강다옥과 $32 \mathrm{P} 75$ 가 가장 많았다. 본 시험에서 화성 등 4 지역을 종합 검토해 볼 때 간장과 착수고율은 품종간 차이는 없었다. 도복은 광평옥이 가장 강하였고, 다른 품종들 은 비슷하였다. 후기녹체성은 모든 품종들이 우수하였다. 깨씨무늬병은 시험품종 모두 발병 률이 낮았으며, 검은줄오갈병은 $32 \mathrm{P} 75$ 가 $10.1 \%$ 로 가장 많았으며 광평옥과 강다옥이 $32 \mathrm{P} 75$ 보 다 상대적으로 강한 것으로 나타났다. 생체수 량은 광평옥과 강다옥이 각각 $\mathrm{ha}$ 당 74.85 톤, 76.68톤으로 가장 많았고 P3394가 ha당 64.97 톤으로 가장 적었다. 건물수량은 ha당 18.83 톤 21.92톤, $\mathrm{TDN}$ 수량은 $\mathrm{ha}$ 당 12.73톤 14.52톤 범위로 품종간 차이는 없었다.

\section{V. 인 용 문 헌}

1. 김동암. 1986. 사료작물 : 그 특성과 재배방법. 선진문화사. 서울. pp. 167-198.

2. 김동암. 1996. 제9회 양축농가를 위한 축산기술 세마나 자료. 서울대학교 부설 축산과학기술연구 소.

3. 김동암, 고서봉, 권찬호, 김문철, 한건준, 김종덕, 이광녕, 신동은, 김종근. 1997. 중·북부 및 제주 지역에 적합한 사일리지용 옥수수의 우량품종 평가. 한초지. 17(4):323-328.

4. 문현귀, 손범영, 차선우, 정태욱, 이영호, 서종호,
민황기, 최기준, 허창석, 김석동. 2001. 사일리지 용 옥수수 신품종 “광평옥”. 한육지. 33(4):350351.

5. 이석순, 이진모. 1987. 흑조위축병 다발지역에서 파종기에 따른 silage 옥수수 생산성. 한초지. 7(3):140-145

6. 이석순, 박근용, 박승의, 이상석. 1988. 지역별 애 멸구 발생양상과 옥수수의 흑조위축병 발생. 한 작지. 33(1):74-80.

7. 이종경, 박형수, 김영근, 정종원, 나기준, 김문철, 이성철, 육완방. 2004. 고랭지에서 파종시기 및 수확시기가 사일리지용 옥수수의 생육특성, 건물 수량 및 사료가치에 미치는 영향. 한초지. 24(2): 115-122.

8. 임영철, 정종원, 한성윤, 최기준, 임용우. 2001 대관령지역에서 사료용 옥수수 품종별 생육특성 과 수량성. 한초지. 21(1):39-44.

9. 지희정, 이종경, 김기용, 윤세형, 임영철, 권오도, 이희봉. 2009. 남부지방 논에서 사일리지용 옥수 수 품종의 생육특성, 생산성 및 품질 비교.. 초지 조사료지. 29(1):13-18.

10. Holland, C., W. Kezar, W.P. Kautz, E.J. Lazowski, W.C. Mahanna and R. Reinhart. 1990. The Pioneer Forage Manual-A Nutritional Guide. Pioneer Hi-Bred Int. Inc., Des Moines, IA.

11. Phipps, R. and M. Wilkinson. 1985. Maize silage Chalcombe Publications, Bucks SL7 3PU.

12. Son, B.Y., H.G. Moon, T.W. Jung, S.J. Kim. B.R. Sung, C.S. Huh and S.H. Ryu. 2006. A New Corn Hybrid Cultivar, "Gangdaok" for Silage. Korean J. Breed. 38(2):149-150.

(접수일: 2011년 4월 12일, 수정일 1차: 2011년 5월 23일, 수정일 2차: 2011년 6월 27일, 게재확정일: 2011년 7월 29일) 